\title{
Launching of a cochlear implant program at the Cracow Otolaryngology Clinic
}

\section{Otwarcie programu implantów ślimakowych w Krakowskiej Klinice Otolaryngologii}

\author{
Maciej Wiatr', Kazimierz Niemczyk², Jacek Składzień', Agnieszka Wiatr' \\ ${ }^{1}$ Chair and Clinic of Otolaryngology U] CM \\ ${ }^{2}$ Chair and Clinic of Otolaryngology WUM
}

Article history: Received: 15.12.2018 Accepted: 20.01.2019 Published: 25.02.2019

ABSTRACT: Introduction: It is estimated that hearing impediment affects approximately $12 \%$ of the population. Some forms of hearing disorders can be successfully treated conservatively, while in others surgery plays a key role. Often, therapeutic methods are exhausted and the patient faces the decision about the need for acoustic organ prosthesis. Depending on the causes of anomalies, apparatus for air conduction, bone conduction or cochlear implants is used. A cochlear implant replaces the damaged sensory cells of the inner ear. It constitutes an electronic prosthesis of the acoustic organ, composed of two parts. The internal part (implanted in the inner ear) consists of an implant and electrodes, which conduct electrical signals to the cochlea. The external part consists of a microphone, a speech processor, and a transmitter.

Care report: A 70-year-old patient with deep hearing loss in the right ear and deafness of the left ear. During the interview, the patient denied mechanical injuries of the head and neck, acoustic trauma, inflammation or otorrhea. Based on the conducted tests, qualification otolaryngology, audiology and otoneurology, radiology, surdologopedy and psychology was performed for cochlear implant insertion. The patient was qualified for cochlear implantation in the left ear under general anesthesia. The surgical team was composed of dr hab. Maciej Wiatr, prof. dr hab. Kazimierz Niemczyk, prof. dr hab. Jacek Składzień, MD Agnieszka Wiatr with anesthetic monitoring under the supervision of MD Renata Witkowska. The patient was discharged home on day 7 after surgery in good general and local condition. Simultaneous rehabilitation was started at the Center for Daily Rehabilitation of Hearing and Speech at the Specialist Center of Diagnosis and Rehabilitation for Children and Adolescents with Hearing Disabilities of the Polish Association of the Deaf in Cracow.

KEYWORDS: $\quad$ Cochlear implant, sensorineural deafness, hearing loss treatment

STRESZCZENIE:

Wstęp: Ocenia się, że zaburzenie słuchu dotyczy około 12\% populacji. Niektóre formy zaburzeń słuchu z powodzeniem można leczyć zachowawczo, w innych kluczowe jest postępowanie chirurgiczne. Niejednokrotnie metody terapeutyczne ulegają wyczerpaniu i pacjent stoi przed decyzja o konieczności protezowania narządu słuchu. Zależnie od przyczyn nieprawidłowości stosuje się aparaty na przewodnictwo powietrzne, przewodnictwo kostne czy implanty ślimakowe. Implant ślimakowy zastępuje uszkodzone komórki słuchowe ucha wewnętrznego. Jest to elektroniczna proteza narządu słuchu, złożona z dwóch części. Część wewnętrzna (wszczepiana do ucha wewnętrznego) składa się z implantu i elektrod przewodzących sygnały elektryczne do ślimaka. Część zewnętrzna, złożona jest z mikrofonu, mikroprocesora mowy i transmitera

Opis przypadku: Chory lat 70 z głębokim niedosłuchem odbiorczym ucha prawego oraz głuchotą ucha lewego. W wywiadzie pacjent negował urazy mechaniczne głowy i szyi, urazy akustyczne, stany zapalne czy wycieki z uszu. Na podstawie przeprowadzonych badań przeprowadzono kwalifikacje otolaryngologiczną oraz audiologiczno - otoneurologiczną, radiologiczną, surdologopedyczna oraz psychologiczną do założenia implantu ślimakowego. Pacjent został zakwalifikowany do założenia implantu ślimakowego na ucho lewe w znieczuleniu ogólnym. Przeprowadzono zabieg operacyjny w składzie dr hab. Maciej Wiatr, prof. dr hab. Kazimierz Niemczyk, prof. dr hab. Jacek Składzień, drn. med. Agnieszka Wiatr pod nadzorem anestezjologicznym pod kierunkiem dr n. med. Renaty Witkowskiej. Chory wypisany został do domu w 7 dobie po zabiegu operacyjnym w stanie ogólnym i miejscowym dobrym. Równoczasowo rozpoczęto rehabilitację w Ośrodku Dziennym Rehabilitacji Słuchu i Mowy przy Specjalistycznej Poradni Diagnozy i Rehabilitacji Dzieci i Młodzieży z Wadą Słuchu PZG w Krakowie.

SŁOWA KLUCZOWE: Implant ślimakowy, głuchota odbiorcza, leczenie niedosłuchu 


\section{INTRODUCTION}

It is estimated that hearing impediment affects approximately $12 \%$ of the population. This is a significant medical and social problem. Hearing loss leads to disturbances in the communicative process, as well as limitations in everyday and professional life.

The multifactorial aetiology of hearing impairment makes diagnosis of hearing loss and therapeutic treatment complex. A different clinical picture is observed in cases of patients with sensorineural hearing loss, other ailments and symptoms come to the fore in patients with conductive hearing loss, for example in the course of chronic otitis media or otosclerosis. Some forms of hearing disorders can be successfully treated conservatively, in others surgery is key.

Often times, therapeutic methods are exhausted and the patient faces the decision about the need for prosthesis of the hearing organ. Depending on the causes of abnormalities, apparatus for air conduction, bone conduction or cochlear implants are used.

The cochlear implant replaces the damaged inner ear cells. It is an electronic prosthesis of the hearing organ, composed of two parts. The internal part (implanted in the inner ear) consists of an implant and electrodes that conduct electrical signals to the cochlea. The external part consists of a microphone, a speech microprocessor and a transmitter.

Therapeutic treatment with the assumption of a cochlear implant is used in patients who do not display a satisfactory effect using hearing aids for air conduction, bone conduction, deaf persons and children with congenital deafness $(1,2,3,4,5)$.

When the hearing impairment affects a child, it leads to a delay in the development of speech, and hence, to disorders in the emotional and cognitive sphere as well as delays in development. Every year, 1-3 out of 1,000 children are born with hearing impairment requiring early intervention due to the fact that proper development can be ensured only in this way. Lack of proper auditory stimuli in the form of ambient sounds and human speech sounds disturbs proper auditory development and development of verbal speech in these children as well as their general development. The operation of cochlear implantation in children between the first and second year of life, gives the best results as it allows deaf children to develop properly and undertake school education equally with children with normal hearing as well as remove barriers in communication with other people $(6,7,8,9,10,11)$.

Treatment with cochlear implants has been used in the world for over 40 years.

In Poland, the first such procedure was performed in 1992 in the Chair and Clinic of Otolaryngology of the Medical University of Warsaw headed by Professor Grzegorz Janczewski.

In European Union countries an average of 8-12 such treatments per one million inhabitants are performed. This applies to countries of Western Europe; in Poland this indicator is significantly smaller.
From November 26, 2014, the Cracow Centre has joined the group of Clinical Centres implanting cochlear implants (Warsaw, Szczecin, Poznań, Katowice, Lublin, Nadarzyn, Białystok, Łódź, Gdańsk), which after many years of preparation has carried out implantation in a 70-year-old man.

\section{CASE REPORT}

A 70-year-old patient was referred to the Acute Admissions Unit of the Department of Otolaryngology in Cracow of the District Laryngological Clinic for the purpose of diagnosing and establishing the healing process. In the interview he reported profound hearing loss in the right ear and deafness in the left ear. The patient remained under laryngological and audiological control at the Laryngological Clinic for about 15 years. Specular laryngological examination revealed: R/L ear without abnormalities. Right ear aided by air conduction apparatus for 10 years. Left ear - hearing loss increasing for several decades, no benefits from the use of apparatus for 15 years, currently the ear is deaf. In the interview, the patient denied mechanical injuries of the head and neck, acoustic trauma, inflammation or draining ears.

In VNG, assessment of peripheral function of the balance organ performed before the insertion of cochlear implant (November 22, 2018), symmetrical vestibular responses were found.

Ear HRCT was performed (11/23/2018): Right mastoid process with sclerotic manifestations - as if after past inflammation. Preserved right mastoid air cells, without the presence of exudate. The left mastoid process is properly aerated. Ear canal patent - symmetrical. Discreetly thickened right eardrum. Tympanic cavity aerated bilaterally, properly formed. The ossicular chain and the connections in-between are correct. The structure of the stapes is visible bilaterally. Attention is paid to increased sclerosis of the bone structure around the inner ear structures biaurally. What is more, attention is paid to the area of the bone structure thinning along the outline of the oval window from the top and front dimensions of about $2.7 \times 1.9 \times 1.6 \mathrm{~mm}$; the second focus of attenuation is visible in the vicinity of the oval window spreading towards the rear and medially from the coil of the basal coil of the cochlea. Similar foci of attenuation are visible around the bony cochlea on the left - towards the front with dimensions $2.7 \times 2.3 \times 2.1 \mathrm{~mm}$, forward of the oval window with dimensions $2.4 \times 1.9 \times 1.8 \mathrm{~mm}$, towards the back and medially from the cochlea, two foci with diameters of $2.4 \mathrm{~mm}$ and $1.5 \mathrm{~mm}$. The image raises suspicions of window and cochlear otosclerosis. No semicircular canal fistula is found. Nerve canal VII bilaterally symmetrical normal in all sections. Tops of the pyramids of the temporal bone without any visible lesions (Fig. 3).

Based on the performed tests, qualification otolaryngology, audiology and otoneurology, radiology, surdo speech therapy and psychology were performed for placing a cochlear implant. The patient was qualified to place a cochlear implant on the left ear under general anaesthesia.

Surgery was performed in the composition of dr hab. Maciej Wiatr, prof. dr hab. Kazimierz Niemczyk, prof. dr hab. Jacek Składzień, 


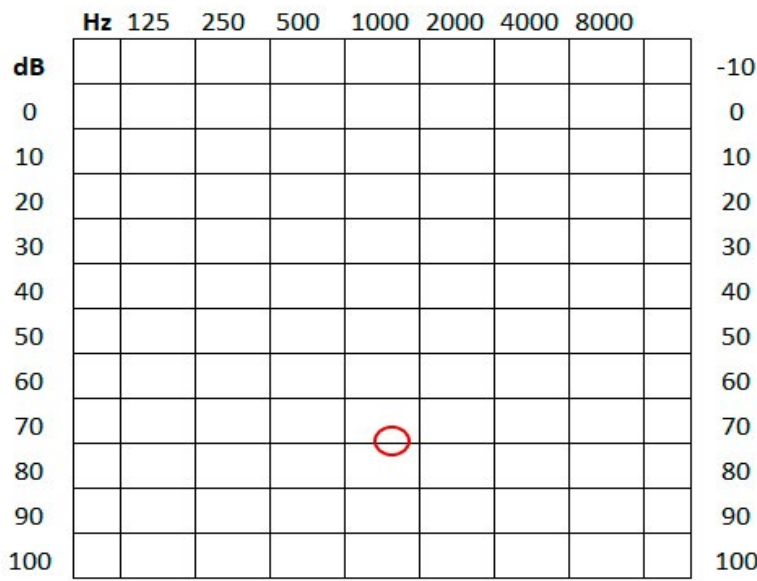

Left ear - no reference in tonal audiometry

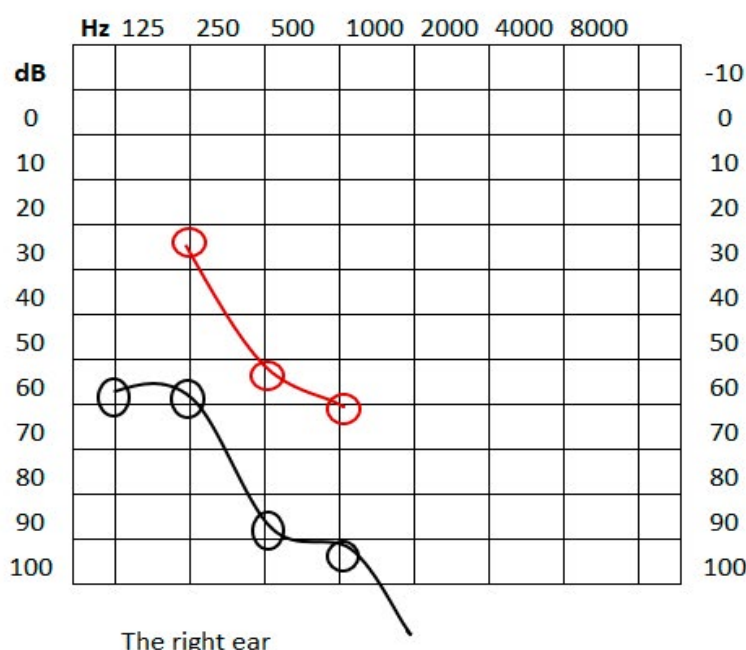

Airy

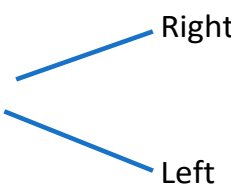

(black)
Bony

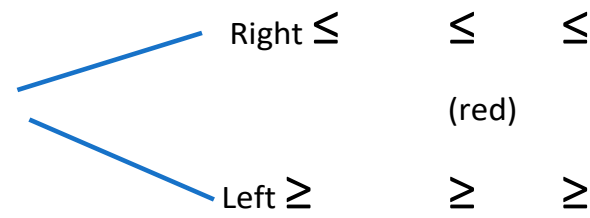

Free field test

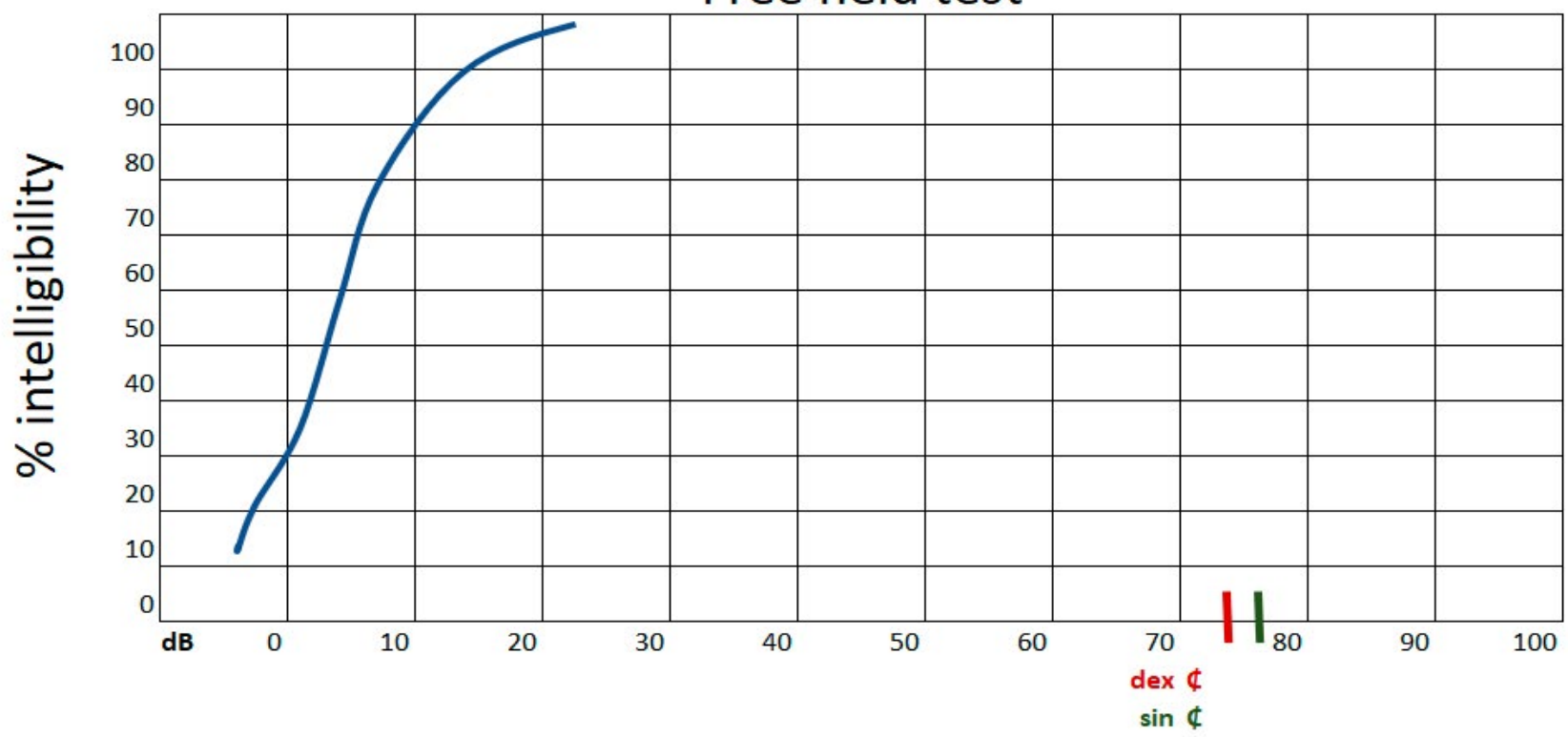

Fig. 1. Pure tone audiometry and speech audiometry.

dr n. med. Agnieszka Wiatr under anaesthesia supervision under the direction of dr n. med. Renata Witkowska.

Neuro Zti EVO implant (Oticon, Denmark) was implanted into the left ear under general anaesthesia according to the protocol.
A left-sided incision was made behind the ear and a cutaneous muscular flap was performed, which covered the inner part of the implant lying on the temporal squama in the next stage. At a later stage, antromastoideectomy was performed, followed by posterior tympanotomy with visualisation of the round window niche. 


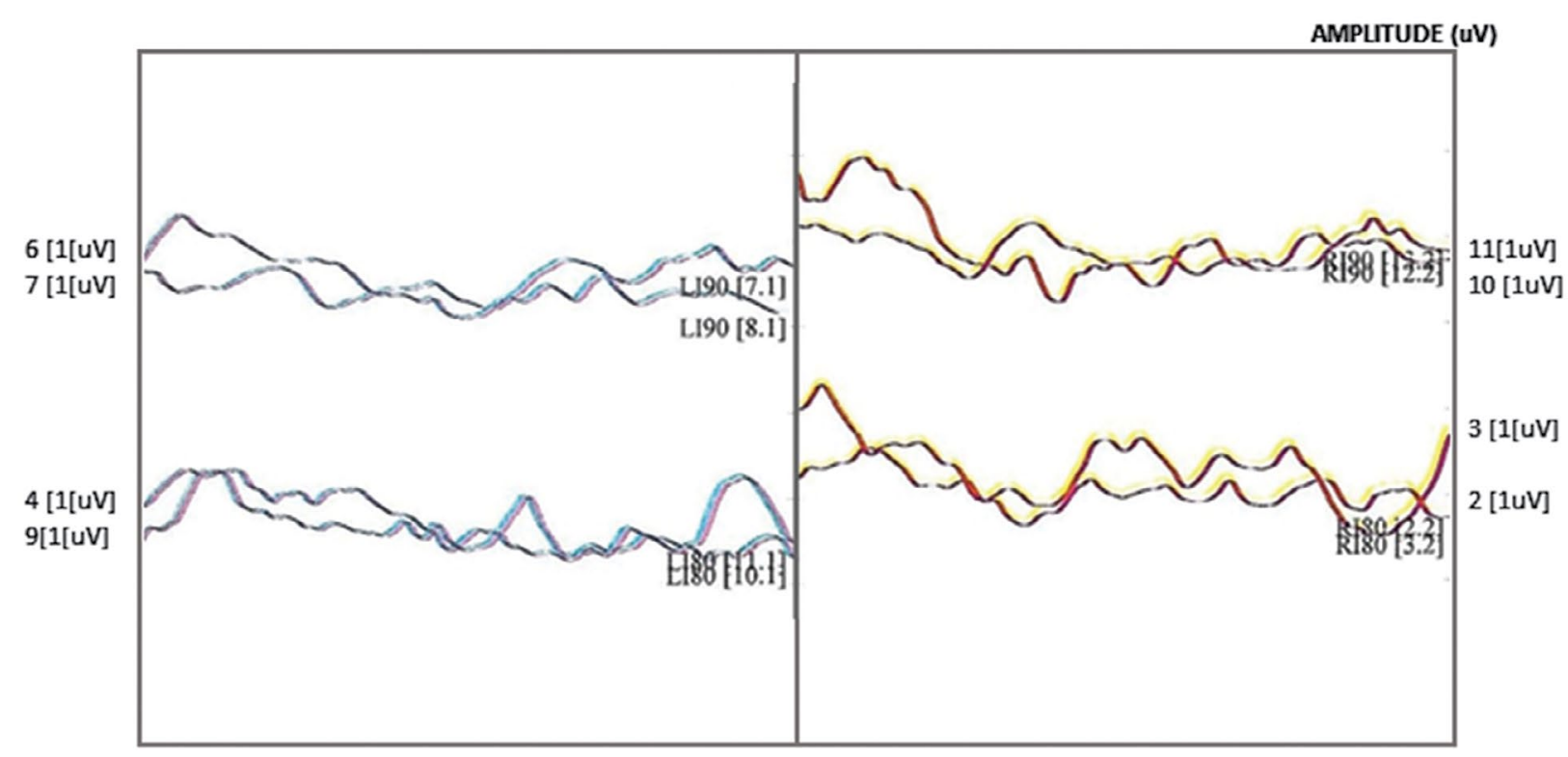

TIME (ms)

Crash 2.1-4 kHz - No response at $90 \mathrm{~dB}$ - Both ears

\begin{tabular}{|c|c|c|c|c|c|c|c|c|c|c|c|c|c|c|c|}
\hline & \multicolumn{15}{|c|}{$\begin{array}{c}\text { WAYEFORMS } \\
\text { ABR }\end{array}$} \\
\hline$\#$ & Date & & Transducer & $\mathrm{nHL}$ & Ear & Rate & Stimulus & Galn & High & Low & ACC & Rej & Epoch & Time/div & Delay \\
\hline 3 & 17.10 .2018 & 32 & Hcaopnones & $800 \mathrm{~B}$ & Rignt & $27.7 / \mathrm{s}$ & Click-A & $100 \mathrm{~K}$ & $100 \mathrm{~Hz}$ & $1.5 \mathrm{kHz}$ & 443 & 184 & $15 \mathrm{~ms}$ & $1.50 \mathrm{~ms}$ & $0.5 \mathrm{~ms}$ \\
\hline 4 & 17.10 .2018 & 10.1 & Hcadphones & $800 \mathrm{~B}$ & Left & $27.7 / \mathrm{s}$ & Click-A & $100 \mathrm{~K}$ & $100 \mathrm{~Hz}$ & $1.5 \mathrm{kHz}$ & 321 & 138 & $15 \mathrm{~ms}$ & $1.50 \mathrm{~ms}$ & $0.5 \mathrm{~ms}$ \\
\hline 6 & 17.10 .2018 & 7.1 & Hcaopnones & $900 \mathrm{~B}$ & Left & $27.7 / 5$ & Click-A & $100 \mathrm{~K}$ & $100 \mathrm{~Hz}$ & $1.5 \mathrm{kHz}$ & 677 & 316 & $15 \mathrm{~ms}$ & $1.50 \mathrm{~ms}$ & $0.5 \mathrm{~ms}$ \\
\hline 10 & 17.10 .2018 & 12.2 & Hcaopnones & $900 \mathrm{~B}$ & Rignt & $27.7 / \mathrm{s}$ & Click-A & $100 \mathrm{~K}$ & $100 \mathrm{~Hz}$ & $1.5 \mathrm{kHz}$ & 2080 & 467 & $15 \mathrm{~ms}$ & $1.50 \mathrm{~ms}$ & $0.5 \mathrm{~ms}$ \\
\hline 11 & 17.10 .2018 & 13.2 & HeaOpnones & $900 \mathrm{~B}$ & Rignt & $27.7 / \mathrm{s}$ & Click-A & $100 \mathrm{~K}$ & $100 \mathrm{~Hz}$ & $1.5 \mathrm{kHz}$ & 213 & 76 & $15 \mathrm{~ms}$ & $1.50 \mathrm{~ms}$ & $0.5 \mathrm{~ms}$ \\
\hline
\end{tabular}

WAVEFORM COMMENTS

ABR

\begin{tabular}{|c|c|c|}
\hline & Waveform & Comments \\
\hline 2 & (Smooth 2.2 -7 points) & \\
\hline 3 & (Smooth 3.2 -7 points) & \\
\hline 4 & (Smooth 10.1-7 points) & \\
\hline 6 & (Smooth 7.1 -7 points) & \\
\hline 7 & (Smooth 8.1-7 points) & \\
\hline 9 & (Smooth 11.1 -7 points) & \\
\hline 10 & (Smooth 12.2 -7 points) & \\
\hline 11 & (Smooth13.2-7 points) & \\
\hline
\end{tabular}

Fig. 2. ABR (22.11.2018): Crackle 2-4 kHz. No response at $90 \mathrm{~dB}$ stimulus binaurally.

Cochleostomy was performed. After opening the inner ear, the implant electrode was placed into the scala tympani with sealing of the connective tissue (Fig. 4).

At the final stage, the inner part of the implant was attached to the temporal squama using two screws and layer sewing was performed on the cutaneous wound. The conducted surgery and post-operative period without complications.
So far, these types of implants have been placed in patients at the Otolaryngology Clinic in Warsaw, the Institute of Physiology and Pathology of Hearing in Kajetany, Szczecin and Łódź.

An inserted implant is one of the smallest devices available on the Polish market. Its operation is based on a different coding strategy for speech signal in comparison to that previously used. Sound is converted into a digital signal, and the coding is based on small 


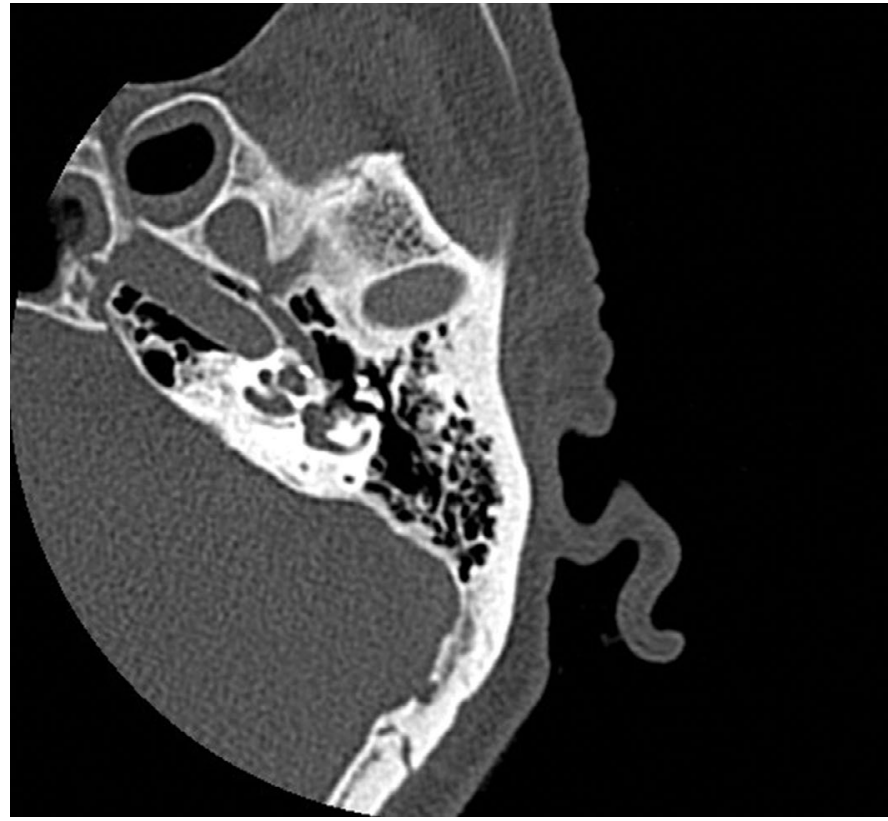

Fig. 3. HRCT of implanted ear.

time differences of an enormous number (several dozen thousand) of electrical signals reaching the ends of the auditory nerve within a second. Digital signal processing allows more complete elimination of unwanted sounds, mainly noise, and the implant user can hear human speech more clearly. Implantation does not require the use of the so-called dagger or a special guide, thanks to which the electrode array is placed in the scala tympani. After inserting the cochlear implant components, assessment of the placed implant and auditory pathway activity was performed using a speech processor configured with the appropriate computer software. The patient was discharged home on the 7th day after surgery in good general and local condition with primary adhesion of the wound, without nystagmus or dizziness. The patient can take any position and he does not report headaches.

\section{References}

1. Lachowska M., Lukaszewicz-Moszynska Z., Mikolajewska A., Lachowska L., Morawski K., Niemczyk K.: Hearing restoration with cochlear implantation in patients deafened after blunt head trauma. Int. Adv. Otol. 2018;14 (3): 347-352.

2. Wilson B.S.: The cochlear implant and possibilities for narrowing the remaining gaps between prosthetic and normal hearing. World J. Otorhinolaryngol. Head Neck Surg. 2018; 3 (4): 200-210.

3. Mosnier I., Sterkers O., Bebear J.P. et al.: Speech performance and sound localization in a complex noisy environment in bilaterally implanted adult patients. Audiol. Neurootol. 2009; 14 (2): 106-114.

4. Lachowska M., Pastuszka A., Lukaszewicz-Moszynska Z., Mikolajewska L., Niemczyk K.: Cochlear implantation in autistic children with profound sensorineural hearing loss. Braz. Journal Otorhinolaryngol. 2018, 84 (1): 15-19.

5. Brown K.D., Balkany T.J.: Benefits of bilateral cochlear implantation: a review. Cur.r Opin. Otolaryngol. Head Neck Surg. 2007; 15 (5): 315-318.

6. Entwisle L.K., Warren S.E., Messersmith J.J.: Cochlear implantation for children and adults with severe-to-profound hearing loss. Semin. Hear. 2018; 39(4): 390-404.

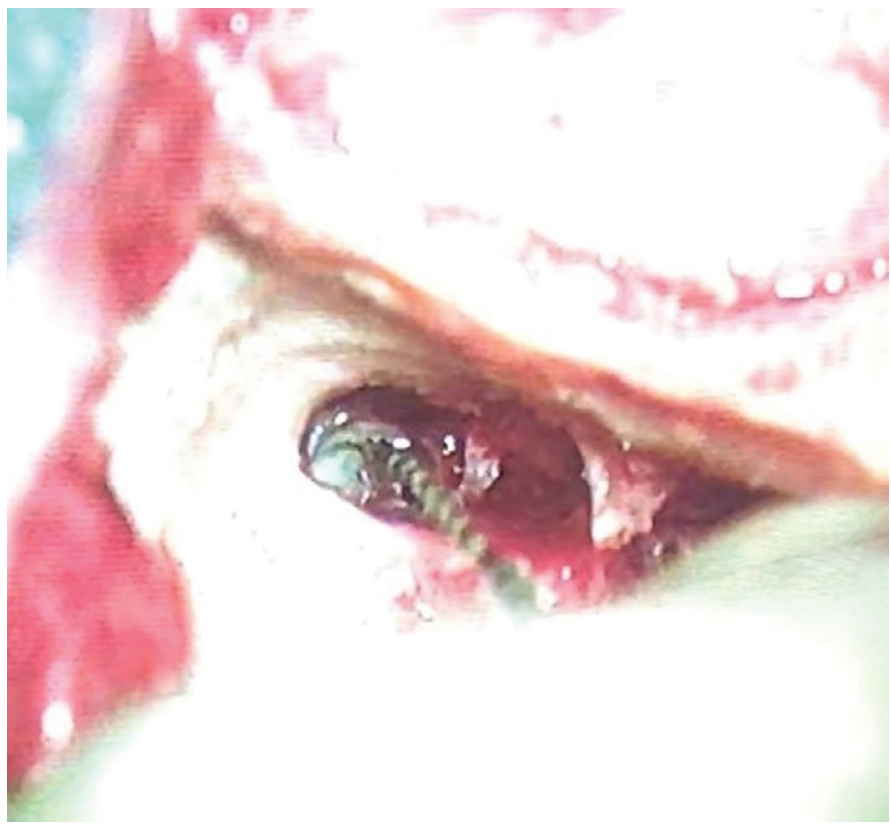

Fig. 4. A cochlear implant electrode was placed into the scala tympani.

In post-operative conduct, the speech processor is planned for activation after complete healing of the wound behind the ear, four weeks after surgery. Programming of the speech processor was carried out by setting appropriate parameters of electrical stimulation. At appropriate intervals, examination and consultation (audiology, ENT, logopaedic and psychological) as well as follow ups and implant placement have been planned (during the first 6 months after implantation once a month, up to 1.5 years after surgery every 2 months, then every 6 months).

Rehabilitation is conducted by the Centre for Daily Rehabilitation of Hearing and Speech at the Specialist Centre of Diagnosis and Rehabilitation for Children and Adolescents with Hearing Disabilities of the Polish Association of the Deaf in Cracow.
7. Lachowska M., Pastuszka A., Glinka P., Niemczyk K.: Benefits of cochlear implantation in deafened adults. Audiol. Neurootol. 2014; 19 (1): 40-44.

8. Cohen S.M., Svirsky M.A.: Duration of unilateral auditory deprivation is associated with reduced speech perception after cochlear implantation: A single-sided deafness study. Cochlear Implants Int. 2018; 28: 1-6.

9. Finke M., Strauß-Schier A., Kludt E., Büchner A., Illg A.: Speech intelligibility and subjective benefit in single-sided deaf adults after cochlear implantation. Hear Res. 2017; 348: 112-119.

10. Laszig R., Aschendorff A., Stecker M. et al.: Benefits of bilateral electrical stimulation with the nucleus cochlear implant in adults: 6-month postoperative results. Otol. Neurotol. 2004; 25 (6): 958-968.

11. Lachowska M., Pastuszka A., Glinka P., Niemczyk K.: Is cochlear implantation a good treatment method for profoundly deafened elderly? Clin. Interv. Aging. 2013; 8: 1339-1346. 
REVIEW ARTICLE

Word count: 1720 Tables:- Figures: 4 References: 11

Access the article online: DOI: 10.5604/01.3001.0013.1410

Table of content: https://otorhinolaryngologypl.com/issue/11876

Corresponding author: dr ha. med. Maciej Wiatr; Katedra i Klinika Otolaryngologii, Uniwersytet Jagielloński, Collegium Medicum, Kraków, Polska; e-mail: mwiatr@mp.pl

Copyright @ 2019 Polish Society of Otorhinolaryngologists Head and Neck Surgeons. Published by Index Copernicus Sp. z o.o. All rights reserved

Competing interests: The authors declare that they have no competing interests.

Cite this article as: Wiatr M., Niemczyk K., Składzień ]., Wiatr A.: Launching of a cochlear implant program at the Cracow Otolaryngology Clinic; Pol Otorhino Rev 2019: 8(1): 1-6 